UDC 141:316.77:004.04

\author{
D. L. KOBELIEVA ${ }^{1 *}$, N. M. NIKOLAIENKO ${ }^{2 *}$ \\ ${ }^{1 *}$ State Biotechnological University (Kharkiv, Ukraine), e-mail daliakobelieva@gmail.com, ORCID 0000-0003-3139-1561 \\ ${ }^{2 *}$ State Biotechnological University (Kharkiv, Ukraine), e-mail Nnataliya196513@gmail.com, ORCID 0000-0003-1700-6540
}

\title{
From Information Search to the Loss of Personality: The Phenomenon of Dataism
}

Purpose. The research is devoted to the analysis of the urgent problem of the information society: the overload of a person with information and, as a result, the impossibility of adequate formation and development of the personality; as well as the problem of "digitization" of human existence and the formation of a new reality of dataism. Theoretical basis. A lot of modern scientific works are devoted to the analysis of the information society, its problems and features. The information society is a logical continuation of the scientific and technological revolution, which led to the rapid growth of scientific knowledge and the technology development. In the 20th century, technologies have touched the sphere of knowledge and information, as a result of which the formation and development of the information society, or "knowledge society", takes place. Information becomes the main resource in it, and, one way or another, a person's life is inextricably connected with the information space. With the information society formation, the problem of information search and processing becomes one of the most urgent. It turns out that despite the abundance and availability of information, it is very difficult to determine its relevance. A lot of effort is spent on developing information retrieval algorithms. Another problem is related to the person's inability to process large amounts of data. This situation begins to influence not only the education process and professional activity, but also the formation of a person's personality. A person is "lost" in the information space and gradually loses his/her "I". Algorithms for data analysis come to the rescue, but gradually, instead of giving a person material for thought, they begin to make decisions on their own, and therefore, live life instead of a person. With the advent of Big Data processing algorithms, a new ideological paradigm appears - dataism, which predicts the merger of a person with the general data flow. Originality. The authors make assumptions that the dataistic future is "natural". A lot of works, including in the framework of philosophy, are focused on the problem of "dissolving" a person in the information space and finding ways to overcome it. But, in our opinion, this process is a completely logical continuation of human evolution. Conclusions. Existence of a person as a data flow is not a problem and a threat, but a new dimension of his/her being, and, therefore, requires a careful study and formulation of the main principles of this form of existence.

Keywords: information society; information retrieval; data processing algorithms; human existence; personality; identity; alienation; freedom of will; dataism

\section{Introduction}

Human existence in the modern world is becoming increasingly connected with the information space. Information is becoming the most important resource of the modern world, and perhaps the purpose of existence of modern civilization. Numerous studies in various fields of science, including philosophy, confirm the relevance of "information" phenomenon research. In our opinion, considering the issues related to the information phenomenon analysis, particular attention should be paid to the problem of person's "dissolving" in the information space. Scientists are increasingly drawing attention to the fact that the knowledge and communication system, which was gradually formed due to conscious human activity, is becoming a separate and independent phenomenon, gaining great power and is already beginning to influence the civilization development. In other words, the information space created by a human begins to create him/her.

This raises many complex issues: the growing amount of information and the possibilities of its processing, information quality, the Internet and its role in the information society, the emer- 
gence of algorithms for analyzing Big Data, Grid systems and cloud computing technologies, their influence on human life, etc. Humanity is beginning to understand not only the positive factors posed by the freedom of information dissemination and access, but also the threats arising in this regard. There are growing concerns about the loss of human integrity under the pressure of diverse information, the loss of the ability of independent orientation in life (both virtual and real) and the ability to analyze information, as well as the growing trust in data analysis algorithms and decision-making prerogatives. Thus, a person gradually loses him/herself, his/her personality and becomes no longer an information user, but a product of the information environment. The global information network is turning from an assistant into a master. In the near future, a person may face the fact that his/her existence will be possible only as a data flow.

Within the framework of philosophy, psychology, sociology and other sciences, there is an active discussion of this problem. S. M. Iagodzinskyi in the article "Information Space of the Global Network: Social-Philosophical Aspect" raises the important issue of large volumes of information and its relevance. He also emphasizes: "...what was considered exclusive technology 10-15 years ago, is now a kind of space of social existence" (authors' transl.) (Iagodzinskyi, 2012, p. 67). S. Proleyev (2014) in his article "'Society of Knowledge' as an Anthropological Situation" notes that: "Personality becomes a singularity, and the way of its constitution becomes involvement in information networks" (authors' transl.) (p. 21). O. Zaporozhchenko (2021) studies the problem of "formation of a stable identity in the information society" (authors' transl.) in his article "Traditional and New Forms of Personal Identification in the Information Society". O. I. Zhukova (2010) in her abstract of the thesis "Self, Its Typology and Place in Human Self Determination" notes that: "...person is less and less perceiving him/herself as an integral personality" (authors' transl.). O. Gomilko (2015) in the article "Knowledge Society as a Challenge to Rationality" draws attention to the internal contradictions of the "knowledge society", which, on the one hand, opens new opportunities for a person, and on the other - leads to "regression of human rationality" (authors' transl.) (p. 26). D. G. Dabrarodni (2019) in the article "The Internet as a Technological Basis of Postmodern Culture: L. Ropolyi's Philosophy of the Internet" notes the meaning of the Internet in the formation of a knowledge society and emphasizes the importance and, at the same time, the problematic nature of its study. In addition to the modern and familiar understanding of the Internet, a new vision of this phenomenon is emerging. Increasingly, researchers are predicting the emergence of the Internet of Things (IoT) in the near future, which will literally combine all things and phenomena (Chekletsov, 2016). The formation of a common information space that violates private boundaries also raises certain legal issues, which V. I. Gryb (2017, p. 63) considers in his publication. Thus, the question of private interests and personal will arises. Wouldn't a situation arise where Big Data corporations and algorithms, which in turn are developing through the active use of Grid technologies and Grid networks, deprive people of the need or even the ability to independently analyze information and make decisions?

Thus, the problems of the information society and human existence in it are currently very relevant. But, in our opinion, despite this, the insufficient attention is paid to the question of the possibility of a new worldview paradigm - dataism. D. Brooks for the first time used this term in the article "The Philosophy of Data". He writes: "If you asked me to describe the rising philosophy of the day, I'd say that it is dataism" (Brooks, 2013). D. V. Popov (2020) also notes: "Before our eyes dataism - the 'religion of data' - is born, a quasi-religious worldview based on faith, hope and love for digital technology" (authors' transl.) (p. 25). O. Kyslova (2019) notes in her 
publication that the process of datafication is an important factor in the transformation of the social environment. Y. Harari (2018), an Israeli historian and science popularizer, pays considerable attention to this issue.

Thus, the problem of human existence in the modern information world or even the problem of coexistence with the information world is one of the determinants of modern philosophy. The rapid development of information technology leaves little time to understand the place of a person in the modern world and the process of its informatization; and, in general, does humanity have a chance to keep itself in its current state, does it make sense to adapt to modern technologies or should something be changed in them?

In this study, we will look at how over the past few decades the following situation has developed that from the problem of information search (which is extremely relevant in the information society or a "society of knowledge") people have moved to the problem of finding themselves, their identity and their personality. We will also consider whether the person of the future needs "personality".

\section{Purpose}

The purpose of the study is to draw attention of the scientific community to the formation of a new worldview paradigm of dataism. Given the above, it is possible to assume that in the near future humanity will no longer be able to separate itself from the information sphere, and given its rapid development, we should focus on the problem of "dissolving" the individual in the data flow. Therefore, the task of our study is to make certain recommendations for further human interaction with the information environment.

\section{Statement of basic materials}

Since the Renaissance and the New Age, a certain worldview has been formed, which eventually becomes decisive for modern civilization. This worldview combines two main components: "faith" in human and "faith" in science. Humanism puts a person at the center of the world and endows him/her with almost divine abilities. Gradually, the inner world of a person and his/her projections into the outer world, begin to play a key role in the worldview paradigm. Science supports humanism, and humanism supports science. Humanism allows a person to explore the world and transform it as he/she wishes. Having got rid of external obstacles, science begins rapid development and soon achieves remarkable results, which further assures a person of the correctness of his/her worldview position. Thus, we get a modern humanistic and scientific worldview (Kobelieva, 2020).

The great potential of science became clear in the 20th century. The situation between humanism and science is changing. If humanism still needs scientific results for its prosperity, there are serious doubts about whether science needs humanism. Humanism sets a system of values and goals, priorities and research directions, which is quite logical and not unfounded. In the end, if the technology generated by science destroys a person him/herself, it is likely that the further development of science will also stop. But if we assume that this will not be destruction, but transformation?

In the 20th century, the formation of the information society begins. In such a society, a person gains access to large amounts of information, which completely coincides with the values and goals of the humanistic paradigm regarding the development and self-improvement of the individual. Science and technology are gaining unprecedented opportunities for dissemination. 
As a result, already in the 21st century, humanity is facing problems related to the fact that the information world is getting out of control, constantly improving, acquiring new forms, and a person no longer decides what to do with information, but on the contrary - information controls a person. The question arises - how did humanity get into this situation, and what could be its consequences?

Modern philosophy, in our opinion, can become one of the effective tools for solving the problems of the information society. On the one hand, "...the formation of the information society under the influence of the computer revolution is one of the important factors of cognitive turn in philosophy and science, which, in turn, contributes to further informatization of society" (authors' transl.) (Zahorodniuk, 2019, p. 93), and on the other - the philosophical comprehension of information processes occurring in society, should determine the nature of the problem and the prospects of the modern worldview paradigm. "Today, philosophy faces the challenge of providing a foundational treatment of the concepts and phenomena underlying the information revolution, in order to foster our understanding and guide the responsible construction of our information society" (Baumgaertner \& Floridi, 2016).

In this study, we aim to trace the transition from an information society or "knowledge society" where knowledge and information are the main resource and used to meet human needs (Danilyan, 2008), to a society that will lose its independence and merge with general world information flow (the concept of dataism), in which a person will no longer have any separate status, and, moreover, will not have the opportunity to build any strategy for the future. The transition process is not yet complete, and it is quite possible that the vector of information technology development will turn in the other direction, and therefore the risks that are very likely now, will not materialize, but, in our opinion, it would be very reckless to deny the possibility of the advent of the dataism era. Therefore, one should assess the current situation as adequately as possible, and perhaps take measures to prevent such situations or to define in more detail one's prospects and one's place in the possible future.

The central concept of the information age is the concept of "information", which, in turn, is not unambiguous. S. K. Boell (2017) in the article "Information: Fundamental positions and their implications for information system research, education and practice" provides the following definitions: "information exists independently of humans as part of the physical world; < .. > information exists in signs, but in the observer independent way; $<\ldots>$ information exists only in relation to a subject; a fourth stance assumes information to exist within a sociocultural setting". S. K. Boell believes that each of these assumptions entails very different situations regarding how people can receive and use information, but, in our opinion, all these options exist in parallel, and we should take them into account in further analysis of information society. As information becomes the main resource of modern society, the focus is on how we can or should interact with it. From this point of view, the issue of information search and its relevance comes to the fore. A lot of research in various fields of science is devoted to the study of this problem (Tereschenko, 2018). The research of "...subjective factors in the information search process" (Gwizdka \& Lopatovska, 2009) is also a relevant issue. American mathematician C. Mooers introduced the term "information retrieval" into scientific usage in 1947. Depending on the field of knowledge, the meaning of this concept may vary slightly, but we can rely on the definition according to which, information retrieval is a "search for certain information that meets the information needs of the user" (DSTU 5034:2008, 2009, p. 4) or "search, selection and provision of information according to certain criteria, which meets the pre-set requirements in the information 
request" (authors' transl.) (DSTU 7448:2013, 2014, p. 10). "Information retrieval" also becomes a separate discipline "... which lies at the intersection of library science, computer science, information design, information security, cognitive psychology, linguistics and semiotics" (authors' transl.) (Pitelinsky, 2018, p. 113).

The technical tool that has connected the whole world into a single system is the Internet. "It is the Internet and other related information and communication technologies (ICT) that have become the technological basis of the current stage of civilization development - the society of knowledge" (Dabrarodni, 2019, pp. 32-33). The "society of knowledge" embodies the ideal of the age of science and humanism, realizing the possibility of rapid and diverse intellectual experience. However, research in the field of the Internet and social networks also shows the negative aspects of the information society. For example, S. M. Iagodzinskyi (2012) in his article "Information Space of the Global Networks: Social-Philosophical Aspect" notes: "Despite the fact that the indisputable features of the information society should include the rapid satisfaction of all needs related to information services, the Internet is less and less able to satisfy the demand for quality, valid, and reliable information" (authors' transl.) (p. 68). Among the problems associated with the use of the Internet the increase in so-called junk information, and related difficulties in evaluating information; crisis of scientific knowledge itself; personality destruction are also singled out (Emelin \& Tkhostov, 2013; Proleyev, 2014). Digital space and the latest technologies create the conditions for an unprecedented increase in the amount of information (Big Data, Open data), but only 0.4 percent of the world's big data is analytically processed (Mezhdunarodnyy bank rekonstruktsii i razvitiya, 2016). Useful information is lost, which on the one hand creates conditions for self-actualization of the personality, and on the other - there is a decrease in search and desire for conscious identity that is expressed in the illusory idea of freedom from society and leads to information-technological loneliness and self-isolation of human (Voronova, 2016).

In the end, it turns out that the information society (or "knowledge society") aimed to accelerate scientific progress based on humanistic ideals, on the contrary, starts destroying the humanistic paradigm. To form a personality, "I" concept, without which it is impossible to imagine a modern system of values, a person should be placed in a certain socio-cultural environment. A hundred years ago, there were no problems with this. A person was born in a certain environment, communicated with a limited number of people, followed certain cultural norms and ideals, and, as a result, was formed as a personality, with an integral and relatively stable "I", who has his/her own will, point of view and right and freedom to realize it. The situation of society informatization seems to change this system radically. Having access to a huge amount of information, a person cannot perceive and process it; he/she does not have the opportunity to find a clear and unshakable support for the formation of his/her own "I". There is a serious contradiction between the physical existence of human, which takes place in certain conditions, and his/her virtual existence, which, in fact, is not limited. A person can be part of many virtual communities, find a lot of information on any issue, but he/she is not able to process it. O. Zaporozhchenko writes in the article "Traditional and New Forms of Personal Identification in the Information Society":

...the question about the possibility of forming a stable identity in the in-

formation society arises. There are two radically opposite points of view.

$<\ldots>$ The first evaluates the formation of the information society as a 
condition for qualitative growth of opportunities for personal development. The second approach $<\ldots>$ focuses on those threats to the personality arising in the new environment. (authors' transl.) (Zaporozhchenko, 2021, p. 57)

Zhukova O. I. notes:

High speed of social changes, complication of social interactions make it difficult for a person to develop, assimilate and adopt new norms; they complicate the process of incorporation into a new social reality and, consequently, make the instability of the individual's position a daily phenomenon, both in his/her own eyes and for the others. They create a state of unconnected, disintegrated self-image. (authors’ transl.) (Zhukova, 2010)

Thus, modern culture faces a major problem, which lies in the contradiction between the concepts of humanism and the information society. The reverse process begins: it is not the person who seeks information, but the information that seeks the person. If ten years ago we used the Internet to find what we need (and we knew in advance what we need), now information algorithms themselves "know" better what to present to us as our interests. In the end, we witness the beginning of the transformation process, the transformation of the inner world of human (Khmel, 2021). It is hardly possible to clearly imagine how this process can end, but we already see that the integrity of the human personality, the prerogative of understanding oneself and managing one's life is gradually leaving a person. But where exactly it goes? In our opinion, one of the probable answers is presented in the concept of dataism.

"As a result of the rapid development of information technology, more and more data are being generated in various spheres of human life. In the last decade, the term 'big data' came into circulation" (authors' transl.) (Kurovska, 2019, p. 114). This term refers to a range of technologies for working with large arrays of unstructured data and the process of transforming them into knowledge relevant to a particular audience (Zwass, 2020). And what is Big Data? The fact is that due to the widespread use of information technology, it is possible to get information from literally everything. And, if, a huge amount of information, as it turned out, is rather destructive for the human personality, then nothing like this happens with artificial algorithms. They are able to collect and analyze unlimited arrays of information, and moreover, use the information obtained to further alienate a person from the process of thinking and making decisions. If a person can have a very vague idea of what he/she wants (for different reasons), then algorithms will not "miss" anything, and as a result, will know much better what a person needs. In fact, this is already happening before our eyes, it is happening to us. For example, 
A team who built a model similar to that used by Cambridge Analytica said their model could understand someone as well as a coworker with access to only 10 Facebook likes. With 70 likes they could know them as well as a friend might, 150 likes to match their parents’ understanding, and at 300 likes they could even come to know someone better than their lovers. With more likes, they could even come to know someone better than that person knows themselves. (Parton, 2018)

Not many people find the prospect of "losing" themselves attractive, but at the same time, stopping the process is hardly possible. One of the possible scenarios is dataism. The concept of dataism is still very young, but, in our opinion, it should be looked at carefully. As a result of the rapid spread of the Big Data, a new phase in the evolutionary development of civilization is emerging - a society based on data.

The main factor of social transformations is datafication, which involves

the transition into quantitative form (into 'data') of all phenomena and as-

pects of the world around us, even those that were previously understood

as purely 'qualitative', not quantifiable: human actions, relationships, de-

sires, moods, etc. (Kyslova, 2019)

As a result, from the point of view of dataism, everything can be digitalized. Everything around, including the person him/herself, becomes part of the overall data flow. Let us note that in this process, no separate place for a person is provided. Of course, in the transition phase, algorithms that are actually processing the data flow need those who develop them and determine the purpose. For example, "for now, computers do an excellent job with very well-defined activities, such as optimizing trucking routes, but humans still need to determine the proper goals, interpret results..." (Chui, Manyika, \& Miremadi, 2016). But, in fact, it is difficult to predict how it will end. It is possible that a person will be compared to artificial algorithms of data analysis, and, perhaps, he/she will finally lose his/her individuality. There is already a situation of uncertainty - what is more important: the private interests of the individual or unrestricted information dissemination. It is possible that this issue will become one of the cornerstones in the near future.

As for dataism, for it, the answer to these questions is obvious - no one and nothing should hinder the data movement. Moreover, the value of anything, including human, is measured by his/her contribution to the information space. The end point of the dataism formation should be the formation of the Internet of Things (IoT). "The Internet of Things (IoT) is a qualitatively new stage in the development of the Web, which allows us to connect (both in space and time) any 
physical and virtual objects ('things'), processes, various systems using any algorithms, programs or interfaces" (authors' transl.) (Chekletsov, 2014). Thus, if the Internet technology has allowed free search and dissemination of information, thus realizing the humanistic idea of selfdevelopment and self-improvement, IoT technology will lead to the need to "lose" oneself and "dissolve" in information. Humanity will be immersed in the digital environment, will be fully digital, virtual (Popov, 2020, p. 26).

Y. N. Harari describes the perspective of life with dataism in detail in his books "Homo Deus: A Brief History of Tomorrow" and "21 Lessons for the 21st Century". Dataism considers all phenomena of the world as different forms of data flow. The whole human race can be interpreted as a data processing system. When the Internet of Things will gain strength, Homo Sapiens will simply disappear. But despite this perspective, modern people continue to do everything to bring such a future closer. More and more people are striving to be part of this data flow, losing privacy, independence and individuality. The first step on this path has already been taken. Data processing algorithms such as Google and Facebook know a person better than he/she knows him/herself, and we are gradually beginning to trust them more than ourselves (Harari, 2018). This process takes place without any coercion and looks quite logical. No one doubts that Google Maps knows best which way to go. Thanks to Big Data algorithms, Google has the ability to process huge amounts of information almost instantly, and we consciously rely on these results (Harari, 2016).

Most likely, people do not see anything strange and frightening in these technologies, because they are accustomed to perceive technology as an assistant. Klaus Schwab (2021), for example, believes that "all of these new technologies are first and foremost tools made by people for people". Our "I" determines which result it wants to get and involves any available resources for its implementation. This has been happening for many millennia and has become commonplace for us. We immerse ourselves in the information flow without any hesitation, because we are sincerely convinced that information freedom helps us to realize our ideas, acquire knowledge, build communities for communication and so on. And it really works. But, more and more often, unnoticed by ourselves, we are beginning to translate the responsibility for decision-making into algorithms. For example, even today the "truth" is what falls into the top lines of Google search results (Cadwalladr, 2016).

It can be argued that a person limited by a certain space, time and environment also had little chance of obtaining adequate information. Moreover, often his/her worldview was formed under the influence of one or another ideology. But all this took place in the human world and was proportional to human consciousness. Currently, data analysis systems or algorithms are involved in the process of personality formation. This raises at least two problems: the use of algorithms for someone's benefit (such as advertising) or, conversely, the absence of any elements of human consciousness in this process. Most fears and discussions are related to the first problem, but in our opinion, the second will have much greater consequences.

\section{Originality}

The originality of this work is to make assumptions about the "naturalness" and inevitability of those processes that occur in the modern information society and affect, in particular, human existence. Perhaps, if we consider the transformation processes taking place with a person under the influence of technology not as a problem but as a task, we will be able to better understand the present and better imagine our place in the future, and perhaps define this place. Technology 
really does not oppose human. It is subject to his/her will, and most likely we have a problem not with the fact that artificial intelligence is not subject to humans, but with the fact that people do not understand what they need, what their will is. Mankind continues its evolution; it transforms itself and the environment. The main task of scientists, especially philosophers, is to understand the consequences of these processes, how they can be influenced or perhaps recognized as "natural" and not hinder the transformation of humanity and the transition to another dimension of existence.

\section{Conclusions}

The dataistic future is unlikely to be attractive to human, at least in its modern form. Dataism is often compared to religion because of its commitment to painting images of an "information paradise" and convincing people of the need to be maximally involved in the data flow. Perhaps this is a variant of the modern religious system. But it is important for philosophy to focus on the consequences that the "new future" will have for human existence.

In view of the above, it becomes obvious that a person in the usual sense has a very high chance of ceasing to exist. Futuristic predictions and scenarios often depict the horrific events of the "machine uprising" era, when people begin to struggle with technologies that got out of control. Of course, it is much easier to defeat the enemy if it has a certain image and enters into open confrontation. It is more difficult to win a war when there is no war at all. In our opinion, this is exactly the situation that is happening today. Artificial intelligence does not fight with people, but rather "exhausts" them. It is possible that we are approaching a time when humanity, developing its technology, is gradually exhausting itself. It will not disappear as a result of the victory of "machines", it will simply bring technology to a level where it will no longer make sense to talk about human - human as such will no longer exist. This process will be evolutionary, "painless" and almost unnoticed. In fact, it is already happening.

\section{REFERENCES}

Baumgaertner, B., \& Floridi, L. (2016). Introduction: The Philosophy of Information. Topoi, 35(1), 157-159. DOI: https://doi.org/10.1007/s11245-016-9370-7 (in English)

Boell, S. K. (2017). Information: Fundamental positions and their implications for information systems research, education and practice. Information and Organization, 27(1), 1-16. DOI: https://doi.org/10.1016/ j.infoandorg.2016.11.002 (in English)

Brooks, D. (2013). The Philosophy of Data. The New York Times. Retrieved from https://www.nytimes.com/ 2013/02/05/opinion/brooks-the-philosophy-of-data.html (in English)

Cadwalladr, C. (2016). Google, Democracy and the Truth about Internet Search. Retrieved from http://surl.li/acvsc (in English)

Chekletsov, V. V. (2014). Ot industry 4.0 k prirode 2.0*. Filosofskie nauki, 11, 112-120. (in Russian)

Chekletsov, V. V. (2016). Philosophical and socio-anthropological issues of cyberphysical systems convergent development (blockchain, Internet of things, ai). Philosophical problems of IT and Cyberspace, 1(11), 65-78. (in Russian)

Chui, M., Manyika, J., \& Miremadi, M. (2016). Where machines could replace humans - and where they can't (yet). Retrieved from https://www.mckinsey.com/business-functions/mckinsey-digital/our-insights/wheremachines-could-replace-humans-and-where-they-cant-yet (in English)

Dabrarodni, D. G. (2019). The internet as a technological basis of postmodern culture: L. Ropolyi's philosophy of the internet. Journal of the Belarusian State University. Philosophy and Psychology, 2, 32-38. (in Russian)

Danilyan, V. O. (2008). Informatsiine suspilstvo ta perspektyvy yoho rozvytku $v$ Ukraini (sotsialno-filosofskyi analiz): Monohrafiia. Kharkiv: Pravo. (in Ukrainian) 
DSTU 5034:2008 Informatsiia i dokumentatsiia. Naukovo-informatsiina diialnist. Terminy ta vyznachennia poniat. (2009). (in Ukrainian)

DSTU 7448:2013 Informatsiia i dokumentatsiia. Bibliotechno-informatsiina diialnist. Terminy ta vyznachennia poniat. (2014). (in Ukrainian)

Emelin, V. A., \& Tkhostov, A. S. (2013). Vavilonskaya set: eroziya istinnogo i diffuziya identichnosti v prostranstve interneta. Voprosy filosofii, 1, 74-84. (in Russian)

Gomilko, O. (2015). Knowledge society as a challenge of rationality. Philosophy of Education, 1, 26-37. (in Ukrainian)

Gryb, V. I. (2017). Information society: characteristic and prospects. Informatsiini resursy, intelektualna vlasnist, komunikatsii v osvitno-naukovii ta innovatsiinii sferakh: filosofsko-pravovi ta prykladni aspekty: Materialy kruhloho stolu (Vinnytsia, May 12, 2017) (pp. 61-67). Kyiv: ArtEk. (in Ukrainian)

Gwizdka, J., \& Lopatovska, I. (2009). The role of subjective factors in the information search process. Journal of the American Society for Information Science and Technology, 60(12), 2452-2464. DOI: https://doi.org/ 10.1002/asi.21183 (in English)

Harari, Y. N. (2016). 21 Lessons for the 21st Century. Knygu klubas. (in Russian)

Harari, Y. N. (2018). Homo Deus: A Brief History of Tomorrow. Moscow: Sindbad. (in Russian)

Iagodzinskyi, S. M. (2012). The information space of the global network: social-philosophical aspect. Proceedings of the National Aviation University. Vol.: Philosophy. Cultural Studies, 16(2), 66-69. (in Ukrainian)

Khmel, I. (2021). Humanization of Virtual Communication: from Digit to Image. Philosophy and Cosmology, 27, 126-134. DOI: https://doi.org/10.29202/phil-cosm/27/9 (in English)

Kobelieva, D. L. (2020). Human existence: present and future (philosophical reflections on the ideas of Y. N. Harari). The Journal of V. N. Karazin Kharkiv National University, Series "The Theory of Culture and Philosophy of Science", 61, 90-96. DOI: https://doi.org/10.26565/2306-6687-2020-61-10 (in Ukrainian)

Kurovska, H. V. (2019). "Kukhnia" velykykh danykh. Sotsiotekhnichni vidnosyny ta aktory u tekhnolohiiakh velykykh danykh. Suchasni problemy upravlinnia: Upravlinnia $v$ umovakh tsyfrovykh transformatsii: Zbirnyk materialiv X Mizhnarodnoi naukovo-praktychnoi konferentsii, November 21, 2019, Kyiv, 113-118. (in Ukrainian)

Kyslova, O. (2019). Big Data in the Context of Studying Problems of Modern Society. Visnyk of V. N. Karazin Kharkiv National University. Series "Sociological Studies of Contemporary Society: Methodology, Theory, Methods", 43, 26-33. DOI: https://doi.org/10.26565/2227-6521-2019-43-03 (in Ukrainian)

Mezhdunarodnyy bank rekonstruktsii i razvitiya. (2016). Doklad o mirovom razvitii "Tsifrovye devidenty" 2016: Obzor. Retrieved from https://data.gov.ru/doklad-o-mirovom-razvitii-cifrovye-dividendy-2016-obzorvsemirnogo-banka-2016-god (in Russian)

Parton, S. (2018). The Rise of Dataism: A Threat to Freedom or a Scientific Revolution. Singularity Hub. Retrieved from http://surl.li/actts (in English)

Pitelinsky, K. V. (2018). Synthetic archetype of turtle in cultures of different epoches and peoples. Bulletin of the Moscow International Academy, 2, 112-131. (in Russian)

Popov, D. V. (2020). Dataism - a quasi-religious extension of transformantropic biopolitics. Religioznaya situatsiya $v$ rossiyskikh regionakh: Tezisy dokladov i soobshcheniy Sedmoy vserossiyskoy nauchno-prakticheskoy konferentsii, October 8-9, 2020, Omsk, 25-31. (in Russian)

Proleyev, S. (2014). "Knowledge society" as an Anthropological Situation. Philosophy of Education, 1(14), 7-24. (in Ukrainian)

Schwab, K. (2021). The Fourth Industrial Revolution. Retrieved from https://www.weforum.org/about/the-fourthindustrial-revolution-by-klaus-schwab (in English)

Tereschenko, V. (2018). The analysis of current methods of information search. Transactions of Kremenchuk Mykhailo Ostrohradskyi National University, 3, 26-31. DOI: https://doi.org/10.30929/1995-0519.2018.3.26-31 (in Ukrainian)

Voronova, N. I. (2016). Anthropological modality of information and network culture. Digital society as a cultural and historical context of human development, 73-77. (in Russian)

Zahorodniuk, V. P. (2019). Informatsiine suspilstvo yak peredumova kohnityvnoho povorotu u filosofii. Philosophical Horizons, 42, 92-93. (in Ukrainian)

Zaporozhchenko, O. (2021). Tradytsiini ta novi formy osobystisnoi identyfikatsii $\mathrm{v}$ umovakh informatsiinoho suspilstva. Suchasna psykholohiia: Problemy ta perspektyvy: Zbirnyk naukovykh prats, 2, 52-57. (in Ukrainian) 
Zhukova, O. I. (2010). Samost, ee tipologiya i mesto v samoopredelenii cheloveka (Extended abstract of PhD dissertation). Tomsk State University, Tomsk. (in Russian)

Zwass, V. (2020). Information system. Encyclopedia Britannica. Retrieved from https://www.britannica.com/topic/ information-system (in English)

\section{LIST OF REFERENCE LINKS}

Baumgaertner B., Floridi L. Introduction: The Philosophy of Information. Topoi. 2016. Vol. 35. Iss. 1. P. 157-159. DOI: https://doi.org/10.1007/s11245-016-9370-7

Boell S. K. Information: Fundamental positions and their implications for information systems research, education and practice. Information and Organization. 2017. Vol. 27. Iss. 1. P. 1-16. DOI: https://doi.org/10.1016/ j.infoandorg.2016.11.002

Brooks D. The Philosophy of Data. The New York Times. 2013. URL: https://www.nytimes.com/2013/02/05/ opinion/brooks-the-philosophy-of-data.html

Cadwalladr C. Google, Democracy and the Truth adout Internet Search. 2016. URL: http://surl.li/acvsc

Чеклецов В. В. От industry 4.0 к природе 2.0*. Философские науки. 2014. № 11. С. 112-120.

Чеклецов В. В. Философские и социо-антропологические проблемы конвергентного развития киберфизических систем (блокчейн, Интернет вещей, искусственный интеллект). Философские проблемы информационных технологий и киберпространства. Киберантропология. 2016. № 1 (11). С. 65-78.

Chui M., Manyika J., Miremadi M. Where machines could replace humans - and where they can't (yet). 2016. URL: https://www.mckinsey.com/business-functions/mckinsey-digital/our-insights/where-machines-couldreplace-humans-and-where-they-cant-yet

Доброродный Д. Г. Интернет как технологическая основа культуры постмодерна: философия интернета Л. Ропольи. Журнал Белорусского государственного университета. Философия. Психология. 2019. № 2. C. 32-38.

Даніл'ян В. О. Інформаиійне суспільство та перспективи його розвитку в Украӥні (соиіально-філософський аналіз) : монографія. Харків : Право, 2008. 104 с.

ДСТУ 5034:2008 Інформачія і документачія. Науково-інформачійна діяльність. Терміни та визначення понять. [Чинний від 2009-01-01]. Київ : Держспоживстандарт України, 41 с.

ДСТУ 7448:2013 Інформаиія і документаиія. Бібліотечно-інформаційна діяльність. Терміни та визначення понять. [Чинний від 2014-07-01]. Київ : Мінекономрозвитку України, 45 с.

Емелин В. А., Тхостов А. Ш. Вавилонская сеть: эрозия истинного и диффузия идентичности в пространстве интернета. Вопросы философии. 2013. № 1. С. 74-84.

Гомілко О. Суспільство знань як виклик раціональності. Філософія освіти. 2015. № 1. С. 26-37.

Гриб В. І. Інформаційне суспільство: характеристика і перспективи. Інформаційні ресурси, інтелектуальна власність, комунікаиії в освітньо-науковій та інноваційній сферах: філософсько-правові та прикладні аспекти : матеріали круглого столу (Вінниця, 12 травня 2017 р.). ВДПУ, НДІІП НАПрН України. Київ : АртЕк. С. 61-67.

Gwizdka J., Lopatovska I. The role of subjective factors in the information search process. Journal of the American Society for Information Science and Technology. 2009. Vol. 60. Iss. 12. P. 2452-2464. DOI: https://doi.org/ 10.1002/asi.21183

Харари Ю. Н. 21 урок для ХХІ века. Knygu klubas, 2016. 336 c.

Харари Ю. Н. Ното Deus: Краткая история завтрашнего дня. Москва : Синдбад, 2018. 496 с.

Ягодзінський С. М. Інформаційний простір глобальних мереж: соціально-філософський аспект. Вісник НАУ. Серія: Філософія. Культурологія. 2012. Т. 16. № 2. С. 66-69.

Khmel I. Humanization of Virtual Communication: from Digit to Image. Philosophy and Cosmology. 2021. Vol. 27. P. 126-134. DOI: https://doi.org/10.29202/phil-cosm/27/9

Кобелєва Д. Л. Буття людини. Сучасність та майбутнє (філософські роздуми щодо ідей Ю. Н. Харарі). Вiсник Харківського наиіонального університету імені В. Н. Каразіна. Серія "Теорія культури і філософія науки". 2020. № 61. C. 90-96. DOI: https://doi.org/10.26565/2306-6687-2020-61-10

Куровська Г. В. "Кухня" великих даних. Соціотехнічні відносини та актори у технологіях великих даних. Сучасні проблеми управління: управління в умовах цифрових трансформацій. Зб. матеріалів Х Міжнар. наук.-практ. конф. (Київ, 21 лист. 2019 р.). КПІ ім. Ігоря Сікорського. Київ, 2019. C. $113-118$. 
Кислова О. М. Соціальні наслідки big data: даніфікація соціального життя. Вісник Харківського національного університету імені В. Н. Каразіна. Серія "Соціологічні дослідження сучасного суспільства: методологія, теорія, методи". 2019. № 43. С. 26-33. DOI: https://doi.org/10.26565/2227-6521-201943-03

Доклад о мировом развитии "Цифровые девиденты" 2016 : обзор / Международный банк реконструкции и развития. 2016. 58 c. URL: https://data.gov.ru/doklad-o-mirovom-razvitii-cifrovye-dividendy-2016-obzorvsemirnogo-banka-2016-god

Parton S. The Rise of Dataism: A Threat to Freedom or a Scientific Revolution. Singularity Hub. 2018. URL: http://surl.li/actts

Пителинский К. В. Синтетический архетип Черепахи: опыт информационного поиска. Вестник Московской международной академии. 2018. № 2. С. 112-131.

Попов Д. В. Датаизм - квазирелигиозное расширение трансформантропной биополитики. Религиозная ситуаиия в российских регіонах. Тезисы докладов и сообщений Седьмой всероссийской научнопрактической конференции (Омск, 8-9 окт. 2020 г.). Омск, 2020. С. 25-31.

Пролеєв С. "Суспільство знань" як антропологічна ситуація. Філософія освіти. 2014. № 1 (14). С. 7-24.

Schwab K. The Fourth Industrial Revolution. 2021. URL: https://www.weforum.org/about/the-fourth-industrialrevolution-by-klaus-schwab

Терещенко В. В. Аналіз сучасних методів інформаційного пошуку. Вісник КрНУ імені Михайла Остроградського. 2018. Вип. 3 (110). С. 26-31. DOI: https://doi.org/10.30929/1995-0519.2018.3.26-31

Воронова Н. И. Антропологическая модальность информационно-сетевой культуры. Цифровое общество как культурно-исторический контекст развития человека : сборник научных статей. 2016. C. 73-77.

Загороднюк В. П. Інформаційне суспільство як передумова когнітивного повороту у філософії. Філософські обрії. 2019. № 42. С. 92-93.

Запорожченко О. Традиційні та нові форми особистісної ідентифікації в умовах інформаційного суспільства. Сучасна психологія: проблеми та перспективи : збірник наукових праць. 2021. № 2. С. 52-57.

Жукова О. И. Самость, ее типология и место в самоопределении человека : автореф. дис. ... д-ра филол. наук. Томский гос. ун-т. Томск, 2010. 45 с.

Zwass V. Information system. Encyclopedia Britannica. 2020. URL: https://www.britannica.com/topic/informationsystem

\author{
Д. Л. КОБЕЛСВА ${ }^{1 *}$, Н. М. НІКОЛАСНКО ${ }^{2 *}$ \\ 1* Державний біотехнологічний університет (Харків, Україна), ел. пошта daliakobelieva@gmail.com, \\ ORCID 0000-0003-3139-1561 \\ 2* Державний біотехнологічний університет (Харків, Україна), ел. пошта Nnataliya196513@gmail.com, \\ ORCID 0000-0003-1700-6540
}

\title{
Від пошуку інформації до втрати особистості: феномен датаїзму
}

Мета. Дослідження присвячено аналізу актуальної проблеми інформаційного суспільства: перевантаженість людини інформацією та, як результат, неможливість адекватного формування й розвитку особистості, а також "оцифровування" буття людини та становлення нової реальності датаїзму. Теоретичний базис. Чимало сучасних наукових робіт присвячено аналізу інформаційного суспільства, його проблем та особливостей. Інформаційне суспільство є логічним продовженням науково-технічної революції, яка призвела до стрімкого зростання наукових знань і розвитку технологій. У XX столітті технології торкнулись сфери знання та інформації, в результаті чого відбувається становлення та розвиток інформаційного суспільства або "суспільства знань". Головним ресурсом у ньому стає інформація, і, так чи інакше, життя людини нерозривно пов'язане з інформаційним простором. Із становленням інформаційного суспільства проблема пошуку та обробки інформації стає однією з найбільш актуальних. Виявляється, що, не зважаючи на велику кількість інформації та іiї доступність, дуже складно визначити іiі релевантність. Багато зусиль витрачається на розробку алгоритмів пошуку інформації. Інша проблема пов'язана із нездатністю людини до обробки великих масивів даних. Така ситуація починає впливати не тільки на процес навчання і професійну діяльність, але й на формування особистості людини. Людина "губиться" в інформаційному просторі і по- 
ступово втрачає своє "Я". На допомогу їй приходять алгоритми аналізу даних, але поступово, замість того, щоб давати людині матеріал для роздумів, вони починають самостійно приймати рішення, а отже, проживати життя замість людини. Із появою алгоритмів обробки Великих даних виникає нова світоглядна парадигма - датаїзм, яка прогнозує злиття людини із загальним потоком даних. Наукова новизна. Автори висувають припущення щодо "природності" датаїстичного майбутнього. Чимало робіт, в тому числі в межах філософії, зосереджено на проблемі "розчинення" людини в інформаційному просторі та пошуку шляхів іiі подолання. Але, на нашу думку, цей процес є цілком логічним продовженням людської еволюції. Висновки. Буття людини як потік даних є не проблемою і загрозою, а новим виміром їі буття і потребує уважного вивчення та формулювання головних засад іiї існування.

Ключові слова: інформаційне суспільство; інформаційний пошук; алгоритми обробки даних; буття людини; особистість; ідентичність; відчуження; свобода волі; датаїзм

Received: 28.07.2021

Accepted: 03.12.2021 